\title{
Slowing Aging via Joint Rhythmic Exercise and Optimized Eating Behavior: Nature Enthuses
}

\author{
Akbar Nikkhah ${ }^{*}$ \\ Chief Highly Distinguished Professor, Department of Animal Sciences, University of Zanjan, Iran
}

*Corresponding author: Akbar Nikkhah, Chief Highly Distinguished Professor, Department of Animal Sciences, Faculty of Agricultural Sciences, University of Zanjan, Zanjan, Iran, National Elite Foundation, Tehran, Iran, Tel: +98-24-350-328-01; Fax: +98-24-350-332-02; E-mail: nikkhah@znu.ac.ir

Received date: July 28, 2015, Accepted date: July 29, 2015, Published date: August 04, 2015

Copyright: (C) 2015 Nikkhah A. This is an open-access article distributed under the terms of the Creative Commons Attribution License, which permits unrestricted use, distribution, and reproduction in any medium, provided the original author and source are credited.

\section{Editorial}

This article innovatively describes how aging bioprocess can be slowed down through regular rhythmic exercise and frequent but light daily food meals. Adapting cell to rhythmic supply and oxidation of substrates is a necessity for effective waste management. Infrequent large high-energy food meals must be avoided to not overpressure cells under too high metabolic rates. Aging as a growing bioprocess is increasingly dependent on synchronizing eating and exercise rhythms.

\section{Pragmatic Review}

Aging is growing public health concern worldwide [1]. Improved understanding of life can slow down aging and improve life satisfaction and quality. However, despite the increased average human age mainly due to improved public health over the centuries, the quality of the increased years of lifespan has not often been improved. This implies that although science and technology have advanced, a real profound improvement in pragmatic understanding of life has not substantively occurred [2,3]. This article, thus, innovatively introduces and critically discusses rhythmic exercise alongside eating behavior in slowing the aging bioprocess.

Rhythmic exercise represents a type of regular physical activity that is conducted almost daily and intensely enough to ensure that the major food consumed during the $24-\mathrm{h}$ period is effectively metabolized and waste-managed [4,5]. Rhythmic exercise has a circadian nature and in no ways permits any major substrate overloads in a variety of splanchnic and peripheral cells. Such a rhythmic regular exercise is adequately intense (e.g., causing sweating and high heart beating rate) and relatively durable (e.g., $>30 \mathrm{~min}$ ) to allow extra body fats or fat precursors to be effectively and timely metabolized towards optimal body and psyche fitness and overall health [5-7]. This bioprocess ensures that the individual remains highly satisfied with his/her performance, utility, and service for the betterment of local, national and global societies.

Desirable results from rhythmic regular exercise may not be predictably achieved should eating behavior not appropriately complement the exercise program [8,9]. Because of the augmented substrate supply and induced anabolism shortly after food intake and the higher chances for various types of cell toxicities due to mismanaged waste, the quantity of the food taken in each meal must not exceed certain limits [10]. To elaborate on, assuming a circadian energy requirement of $2000 \mathrm{kcal}$ for an example individual, taking one single large $2000 \mathrm{kcal}$ meal or two $1000 \mathrm{kcal}$ large meals (or even three $667 \mathrm{kcal}$ meals) daily is not considered optimal. Instead, such an energy requirement should be met by taking food meals of no more than $500 \mathrm{kcal}$ at each eating time. Preferably, to emphasize, five 400 $\mathrm{kcal}$, or six $333 \mathrm{kcal}$, or seven $286 \mathrm{kcal}$ daily meals better meet nutrient and metabolic requirements for healthy and quality aging. Notably, it is critical to not consider each food meal fully independent, as it includes also any kind of food that is taken around the major meal as a supplement, such as different fruits, vegetables and desserts.

The above representations describe a joint bioprocess that used to occur when the man was the mentee of the nature. Modernization has kept the man too far from the mother nature [6]. This unhealthy distance has resulted in the emergence of numerous public and individual health issues that seriously jeopardize the quality of the increased human age [10-13]. Obesity, diabetes and cancer continue to harmfully affect human life mainly and foremost due to interrupted synchronies of substrate supply and oxidation [12-15]. Joint practices of rhythmic exercise and optimal eating behavior is a pragmatic strategy to minimize the above interruptions and improve aging bioprocess for quality life.

\section{Conclusion}

This article presented an innovative pragmatic approach to intense, rhythmic and regular physical activity complemented by light and frequent daily food meals as a metabolically and timely appropriate eating behavior. This strategy minimizes risks from substrate overload, imbalanced substrate supply and oxidation, unnecessary substrate deposition, mismanaged waste, various cellular toxicities, inefficient insulin action, depressed endocrinology and immunity, and hastened aging.

\section{Acknowledgment}

The Ministry of Science Research and Technology, National Elite Foundation, and University of Zanjan are thanked for supporting the author's global programs of optimizing science edification in the new millennium.

\section{References:}

1. Nikkhah A (2014) Aging Evolution: A Postmodern Public Apprehension. International Journal of Medicine and Pharmacy 2: 1-22.

2. Nikkhah A (2015) Lifestyle Bioengineering via Scheduled Intake: Bridging Animal Agriculture to Human Medicine. Aust J Biotechnol Bioeng 2: 1045.

3. Nikkhah A (2015) Demolishing Obesity via a Circadian Cutting-Edge Public Science. J J Obesity 1: 008.

4. Nikkhah A (2015) Circadian Timing and Regularity of Physical Activity: A Novel Bioprocess to Prevent Devastating Modern Diseases. J Bioprocess Biotech 5: e131.

5. Nikkhah A (2015) Running as a Postmodern Probiotic to Optimize Gut Physiology and Health. J Prob Health 3: 113. 
Citation: Nikkhah A (2015) Slowing Aging via Joint Rhythmic Exercise and Optimized Eating Behavior: Nature Enthuses. J Bioprocess Biotech 5: e136. doi:10.4172/2155-9821.1000e136

Page 2 of 2

6. Nikkhah A (2015) Nature as an Ideal Rhythm Model for Optimal Cardiovascular physiology and Health. Int J Diabetol Vasc Dis Res 3: 1-2.

7. Nikkhah A (2015) Secure Weight Management via Fitting Circadian Patterns of Physical Activity, Resting and Eating. Adv Weigh Manag Obes Cont 2: 23.

8. Nikkhah A (2015) Circadian Fitting of Exercise and Eating Patterns: The Secret of Healthy Life. J Bioprocess Biotech 5: e129.

9. Nikkhah A (2015) Harmonizing Eating and Exercise Circadian Rhythms for Optimal Glucose-Insulin and Vascular Physiology. Int J Diabetol Vasc Dis Res 3: 87-88.

10. Nikkhah A (2015) Breast Safety Progress through Exercise-Driven Lactation: A Pragmatic Bioprocess to Prevent Cancer. J Bioprocess Biotech 5: e127.
11. Nikkhah A (2015) Intake Circadian Physiology: An Overlooked Public Health Concern. Endocrinol Metab Synd 4: 153.

12. Nikkhah A (2015) Establishing Rhythmic Regularities in Cell Physiology: A Novel Global Program to Thwart Cancer. J Nutr Health Food Eng 2: 00052.

13. Nikkhah A (2015) Wrecked Oncogenesis through Synchronized Substrate Availability and Oxidation: A Novel Bioengineering of Cell Physiology. Aust J Biotechnol Bioeng 2: 1042-1043.

14. Nikkhah A (2015) Untimely intake as a postmodern public health bioterrorism. J. J Bioterror Biodef 7: e118.

15. Nikkhah A (2015) Avoid Large Night Meals to Stay Fit. J Obes Weight Loss Ther 4: e115. 